\title{
Identification of Young Women's Nutrition and Reproductive Knowledge in Making Video on Community-based Learning
}

\section{Guspri Devi Artanti ${ }^{1}$, Rina Febriana ${ }^{2}$, and Rusilanti ${ }^{1}$}

${ }^{1}$ Faculty of Engineering, Universitas Negeri Jakarta, Jakarta, Indonesia

${ }^{2}$ Vocational Education and Engineering, Universitas Negeri Jakarta, Jakarta, Indonesia

\section{Abstract}

The purpose of this study was to identify in detail the nutritional knowledge and reproductive health of adolescent girls as an exploration effort in making interactive learning videos based on community empowerment. In general, this study uses a research and development approach by adopting ADDIE Analysis, Design, Development, Implementation, and Evaluation models. At the Analysis stage, it was carried out by exploiting knowledge of nutrition and reproductive health of female adolescents in the age range of 14-20 years, carried out by a survey method for

Corresponding Author: Guspri Devi Artanti

vie_artanti@yahoo.com

Received: 11 January 2019 Accepted: 14 February 2019 Published: 25 March 2019

Publishing services provided by Knowledge E

(c) Guspri Devi Artanti et al. This article is distributed under the terms of the Creative Commons Attribution License, which permits unrestricted use and redistribution provided that the original author and source are credited.

Selection and Peer-review under the responsibility of the $3 \mathrm{rd}$ ICTVET 2018 Conference Committee.

\section{G OPEN ACCESS} young women aged 14-20 years. The results showed that the mastery of nutritional knowledge in young women scored 65.65, and the aspects of reproductive health knowledge scored 75.25. The conclusion, in general, is that young women's experience of nutrition and reproductive health is still in the low category, so further research is needed in the form of Learning Media Development for Increasing Mothers' Knowledge of Nutrition and Reproductive Health of Community-based Female Adolescents.

Keywords: nutrition knowledge, young women's reproductive knowledge, video

\section{Introduction}

Indonesian teenagers are currently experiencing rapid social change from traditional societies towards modern society, which also changes their norms, values, and lifestyles. Adolescents who were once actively maintained by the family system, traditional customs, and existing traditional values, have experienced erosion caused by rapid urbanization and industrialization. This condition was followed by the media revolution which was open to a variety of lifestyles and career choices. These various things have resulted in the increased vulnerability of adolescents to multiple types of diseases, especially those related to sexual and reproductive health. 
Currently, reproductive health has received particular attention globally since it discussed at the International Conference on Population and Development (ICPD), in Cairo, Egypt, in 1994 [1]. The important thing in the conference was to agree on a change in paradigm in managing population and the development of population control and fertility reduction approaches has become a focused approach to reproductive health and efforts to fulfill reproductive rights.

A correct understanding of human sexuality is needed especially for adolescents for their sexual behavior in adulthood until they are married and have children. Education is needed so that adolescents can avoid risky sexual behavior, which endangers their reproductive and sexual health.

The family is the first and foremost educational environment in the process of educating children. Then family education is essential even the most important and necessary. If there is an error in family education, it will have an impact on the next process. Reproductive health education must be considered part of the educational process, which has the aim of strengthening the basics of knowledge and personality development. Through reproductive health education is an effort for adolescents to improve understanding, knowledge, attitudes, and positive behavior about their sexual and reproductive health, as well as increasing the level of reproduction. 2012 Indonesian Demographic and Health Survey (IDHS) on Adolescent Reproductive Health showed that more than half of women discussed menstruation before getting their first period with friends (53\%) or with their mothers (41\%) [2].

Based on this description, this study aims to identify the level of knowledge of nutrition and reproductive health of young women as a basis in the next stage, namely the development of learning video media for improving understanding of food and Reproductive Health for Teenage Girls as a Preventive Effort.

\subsection{Nutrition of young women}

Adolescent age is an age where there are hormonal changes where changes in physical and psychological structures undergo drastic changes. Adolescence begins at the age of 9-10 years and ends at the period of 18 years. The main nutritional problems experienced by teenagers include iron deficiency anemia, overweight/obesity, lack of nutrients. This problem is related to excessive and increasing consumption of processed foods that are less nutritional value but have many calories as a trigger factor for obesity in adolescence. Consumption of Junk food causes teenagers to be very vulnerable to lack of nutrients and pathological changes in adolescents who are too early [3]. 
The survey noted inadequate nutritional intake in adolescents. Teenagers spend a lot of breakfast time on busy grounds but also tend to consume junk food. Also, concerns of being fat have forced young women to reduce the amount of food that should consume.

TABLE 1: Adolescent and Young Adult Nutritional Needs.

\begin{tabular}{|c|c|c|c|c|c|c|c|}
\hline \multicolumn{3}{|l|}{ Male (Year) } & \multirow[b]{2}{*}{$19-24$} & \multicolumn{3}{|c|}{ Female (Year) } & \multirow{2}{*}{$\begin{array}{l}\text { Teenager } \\
\text { Pregnant }\end{array}$} \\
\hline & $11-14$ & $15-18$ & & $11-14$ & $15-18$ & $19-24$ & \\
\hline Energy (total kkal) & 2500 & 3000 & 2900 & 2200 & 2200 & 2200 & $>300$ \\
\hline Energy (kkal/kg) & 55 & 45 & 40 & 47 & 40 & 38 & - \\
\hline Protein (g) & 45 & 59 & 58 & 46 & 44 & 46 & 60 \\
\hline Vitamin A (mcg) & 1000 & 1000 & 1000 & 800 & 800 & 800 & 800 \\
\hline Vitamin D (mcg) & 10 & 10 & 10 & 10 & 10 & 10 & 10 \\
\hline Vitamin E (mg) & 10 & 10 & 10 & 80 & 80 & 80 & 10 \\
\hline Vitamin K (mcg) & 45 & 65 & 70 & 45 & 55 & 60 & 65 \\
\hline Vitamin C (mg) & 50 & 60 & 60 & 50 & 60 & 60 & 70 \\
\hline Folate (mcg) & 150 & 200 & 200 & 150 & 180 & 180 & 400 \\
\hline Calcium (mg) & 1200 & 1200 & 1200 & 1200 & 1200 & 1200 & 1200 \\
\hline Ferrum (mg) & 12 & 12 & 10 & 15 & 15 & 15 & 30 \\
\hline Zinc (mg) & 15 & 15 & 15 & 12 & 12 & 12 & 5 \\
\hline
\end{tabular}

\subsection{Adolescent reproductive health}

Entering adolescence which begins with the occurrence of sexual maturity, the teenager faced with circumstances that require adjustment to be able to accept the changes that occur. The intended change is the occurrence of physical changes (including physical appearances such as body shape and body proportion) and physiological function (maturity of sexual organs).

According to the International Conference on Population and Development (ICPD) in Cairo, that reproductive health was a complete physical, mental, social welfare in all matters relating to the system, functions, and processes of reproduction and not just conditions that are free of disease or disability. Referring to the concept put forward in the ICPD, the Republic of Indonesia's Ministry of Health provides an understanding that Reproductive Health is a healthy state which encompasses the physical, mental and social life that is related to the tools, functions, and processes of reproduction [4]. While reproductive health according to $\mathrm{WHO}$ is a complete physical, mental and social condition, it is not only free from disease or disability in all aspects related to the reproductive system, its functions, and processes. 
Reproductive health defined as a condition where humans can enjoy their sexual life and can perform their reproductive functions and processes healthily and safely. Generative health thinking is not only a disease-free condition but rather how a person can have a safe and satisfying sex life before and after marriage. Adolescent reproductive health is a health condition that involves the reproductive system, function, and process possessed by teenagers. Healthy understanding here does not merely mean disease-free or free from disability but also mentally and socially healthy.

According to Kusmiran (2011), Health for women is more than reproductive health. Women have unique health needs related to sexual and reproductive functions. Putri has a reproductive system that is sensitive to damage that can occur dysfunction or disease [5].

\section{Methods and Equipment}

\subsection{Methods}

This study uses a research and development approach with the aim to produce a learning model of nutrition and healthy reproduction of female adolescents through development and validation referring to ADDIE models (Analysis, Design, Development, Implementation, and Evaluation) [6].

Data collection was carried out by distributing questionnaires in the form of instruments. The instrument consists of two identified variables, namely nutrition knowledge and knowledge of adolescent reproductive health. This study uses the construct validity test by using the opinions of experts [7]. The first phase in ADDIE is needs analysis, literature study and small research.

\subsubsection{Needs analysis}

This is done by looking for information related to the problems faced by the location or area that is the target of product development. Also, looking for information or data related to what is needed to solve problems. 


\subsubsection{Literature study}

The study deals with information retrieval and empirical data through relevant theories and research related to the product to develop. This will lead researchers to develop products that will be produced.

\subsubsection{Small-scale research}

This research intended as a result of the identification carried out by researchers related to products that are needed to ascertain whether the product that the researcher will develop can genuinely be a product that can solve the problem of educational institutions. In the preliminary stage of the ADDIE stage, activities are carried out: data collection and needs analysis. Exploration knowledge of nutrition and reproductive health of women aged 14-20 years who were carried out by survey method for young women aged 14-20.

\section{Results}

This study conducted on young women aged 14-20 years with as many as 40 respondents. The results showed that mastery of nutritional knowledge in young women resulted in a score of 65.65 . The following are the results of mastering nutritional knowledge based on respondents' answers.

TABLE 2: Nutrition of Young Women.

Number
12
13
14
Total
Average in Total

\begin{tabular}{|c|}
\hline Average \\
\hline 0.969 \\
\hline 0.848 \\
\hline 0.151 \\
\hline 1.968 \\
\hline 0.6565 \\
\hline
\end{tabular}

The aspect of reproductive health knowledge produces a score of 75.25 with details of the score as follows:

The conclusion, in general, is that the experience of young women in nutrition and reproductive health is still in the low category, so the need for further research is in the form of Learning Media Development to Improve Mother's Knowledge of Nutrition and Community-Based Women's Reproductive Health. Teenagers. 
TABLE 3: Adolescent Reproductive Health.

Number
1
2
3
4
5
6
7
8
9
10
11
15
Total

Average in Total

\begin{tabular}{|c|c|}
\hline Average \\
1 \\
1 \\
0.787 \\
1 \\
1 \\
\hline 0.939 \\
0.212 \\
\hline 0.909 \\
0.272 \\
0.09 \\
0.818 \\
1 \\
\hline 9.027 \\
\hline 0.7525 \\
\hline
\end{tabular}

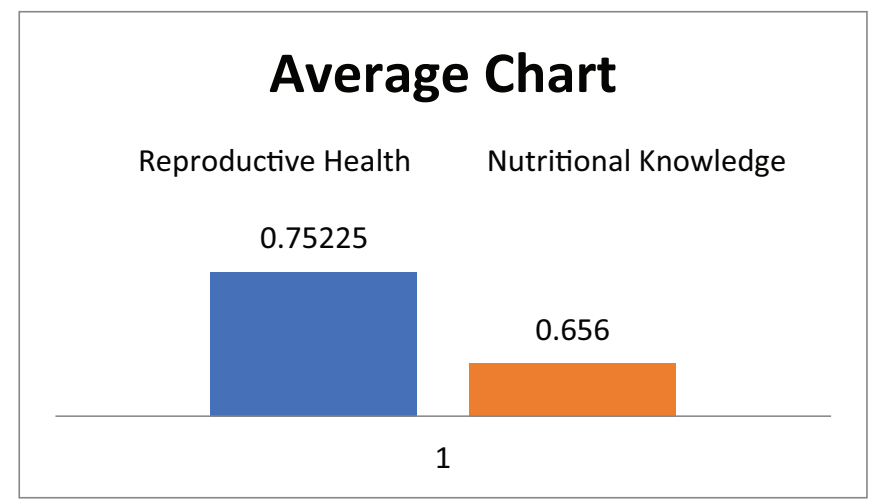

Figure 1: Average value of nutrition knowledge in adolescent reproductive health.

\section{Discussion}

Reproduction is related to the management of population and development problems from the population control approach and fertility decline to a strategy focused on reproductive health and efforts to fulfill reproductive rights. A correct understanding of human sexuality is needed especially for adolescents for their sexual behavior in adulthood until they are married and have children. Education is needed so that teenagers can avoid risky sexual behavior, which endangers their sexual and reproductive health.

Reproductive health education considered as part of the education process, which has the aim to strengthen the basics of knowledge and personality development. Through reproductive health education is an effort for adolescents to improve their 
understanding, knowledge, attitudes, and positive behavior about their reproductive and sexual health, as well as increase their reproductive level.

\section{Conclusion}

Nutritional knowledge and reproductive health are fundamental aspects to be understood by young women. The higher understanding of adolescent nutrition is expected to improve adolescent reproductive health further. Also, having proper nutrition knowledge will avoid reproductive diseases

\section{Funding}

This work was supported by the Faculty of Engineering Universitas Negeri, Jakarta.

\section{Acknowledgement}

The authors would like to thank colleagues for their contributions and support for this research. They are also thankful to all the reviewers who provided their valuable input on this text and helped complete this paper.

\section{Conflict of Interest}

The authors have no conflict of interest to declare.

\section{References}

[1] International Conference on Population and Development. United Nations Populations Fund (UNFPA). 5 September 1994 - 13 September 1994. Cairo, Egypt.

[2] Indonesia's Demographic and Health Survey. (August 2013). National Population and Family Planning Board, Central Statistics Agency. Ministry of Health. MEASURE DHS ICF International.

[3] Khomsiyah K.D. (1998). Patterns of fast food consumption and nutritional status of teenagers are several fast food restaurants in Semarang. Essay. UNDIP Semarang.

[4] Balitbang Kemenkes RI. 2012. Basic Health Research; RISKESDAS. Jakarta: Balitbang Kemenkes RI. 
[5] Kusmiran Eny. (2011). Adolescent and Women's Reproductive Health. Salemba Medika

[6] Tegeh, I. M., Jempel, I. N., Pudjawan, K. (2014). Research and Development Models. Yogyakarta: Graha IImu.

[7] Sugiyono. (2015). Research and Development Methods. Bandung: CV Alfabeta. 